\title{
ВПЛИВ ГАРЯЧОГО ШТАМПУВАННЯ НА СТРУКТУРУ ТА ВЛАСТИВОСТІ ПОРОШКОВИХ ЕКВІАТОМНИХ СПЛАВІВ НА ОСНОВІ СИСТЕМИ Ti-Cr-Fe-Ni
}

Незважаючи на досить тривалий період розвитку матеріалознавства, як одного з найбільш важливих напрямків практичної, а потім і наукової діяльності людини, основою більшості створених і найбільш широко застосовуваних неорганічних матеріалів є один, а рідше два або три металу. В останні десятиліття завдяки швидко наростаючим потребам промисловості в різних конструкційних і функціональних матеріалах розробляються нові високолеговані сплави, в яких поступово збільшується як число легуючих елементів, так і їх частка в загальній масі матеріалів [1-3].

Одним з результатів такого напрямку розвитку матеріалознавства стало створення принципово нового класу металевих матеріалів - високоентропійних сплавів (ВЕСів), що включають до 5-10 основних елементів, які знаходяться в шихтовому стані в еквіатомному (або близькому до еквіатомному) співвідношенні [2-10]. Вважається, що високі механічні властивості ВЕСів забезпечуються головним чином внаслідок гомогенності розподілу різнорідних атомів в твердих розчинах, а також завдяки сильному спотворенню кристалічної решітки внаслідок суттєвої різниці атомних радіусів елементів заміщення. Сплави з такими структурами мають високу твердість, міцність, зносостійкість, стійкість до окислення, тощо.

Переважна більшість створених на сьогоднішній день ВЕСів містять в значних кількостях такі дорогі та дефіцитні елементи, як $\mathrm{Co}, \mathrm{W}, \mathrm{V}, \mathrm{Nb}, \mathrm{Mo}$, Та і т. д., що значно звужує економічну доцільність їх широкого практичного застосування. Це обумовлює доцільність розробки нових компонентних складів таких сплавів на основі менш витратних ресурсозберігаючих підходів з використанням відносно дешевих і доступних складових за умови забезпечення високих фізико-механічних і експлуатаційних властивостей останніх.

У технологічному плані найбільш широко застосовуються в сучасних умовах методи виготовлення ВЕСів базуються головним чином на використанні ливарних технологій, зокрема - вакуумної дугової плавки. Однак, для сплавів, отриманих металургійними методами, притаманні також і традиційні недоліки, характерні для більшості структур литих сплавів. До них відносяться, зокрема, наявність в структурі металу усадочних пор, раковин і дендритних ліквації, які формуються в процесі кристалізації розплавів [9]. Притаманні ливарним сплавам недоліки сприяли розвитку для отримання високоентропійних сплавів методів порошкової металургії, що включають, зокрема, операції механічного легування із суміші елементарних порошків 3 подальшим гарячим статичним (ізостатичним) пресуванням або іскроплазмовим спіканням (SPS) [10, 11].

В той же час відомо, що одним з найбільш ефективних процесів порошкової металургії, що забезпечують отримання щільних (практично безпористих) виробів (в тому числі складної форми), є гаряче штампування пористих заготівок (ГШПЗ) $[12,13]$. Гаряче штампування за рахунок використання, зокрема, схем деформації з розвиненим осередком зсувних деформацій, дозволяє отримувати матеріали з більш дисперсною структурою, підвищеними характеристиками міцності та пластичності внаслідок значного зростання кількості зон розриву оксидних плівок в контактних зонах між частинками і помітного посилення міжзеренних дифузійних процесів зі збільшенням ступеня зсувних деформацій [14-16].

Метою даної роботи було проведення аналізу впливу гарячого штампування пресовок iз порошкових сумішей на основі системи Ti-Cr-Fe-Ni еквіатомного складу на особливості структури та основні властивості отриманих сплавів у порівнянні зі спеченими сплавами аналогічних компонентних складів. 
Матеріали і методики експерименту. В якості вихідних складових шихти для отримання еквіатомних сплавів різних складів використовували порошки Ті (марки ПТХ-6-1), $\mathrm{Cr}(\Pi \mathrm{X}-2 \mathrm{C}), \mathrm{Ni}($ ПНЕ-1), $\mathrm{Fe}$ (ПЖР-3), Cu (ПМС-1) і графіту марки ГК-1. 3 використанням зазначених компонентів готували три склади порошкових сумішей в еквіатомному співвідношенні: $\mathrm{TiCrFeNiCu}, \mathrm{TiCrFeNiCuC} \mathrm{i} \mathrm{TiCrFeNiC}$. Для цього за допомогою комп'ютерної програми HSC Chemistry 5.11 визначали масовий вміст кожного елемента в сумішах, виходячи з їх еквіатомності (табл. 1).

Таблиця 1

Атомний і масовий вміст елементів в порошковій шихті різних складів*

\begin{tabular}{|c|c|c|c|c|c|c|c|}
\hline № & Склад & \multicolumn{7}{|c|}{ Вміст елементів, \% } \\
\cline { 3 - 8 } п/п & шихти & $\mathrm{Ti}$ & $\mathrm{Cr}$ & $\mathrm{Fe}$ & $\mathrm{Ni}$ & $\mathrm{Cu}$ & $\mathrm{C}$ \\
\hline 1 & $\mathrm{TiCrFeNiCu}$ & $20 / 17,2$ & $20 / 18,7$ & $20 / 20,1$ & $20 / 21,1$ & $20 / 22,9$ & - \\
\hline 2 & TiCrFeNiCuC & $16,67 / 16,5$ & $16,67 / 17,9$ & $16,67 / 19,3$ & $16,67 / 20,3$ & $16,67 / 21,9$ & $16,67 / 4,1$ \\
\hline 3 & TiCrFeNiC & $20 / 21,2$ & $20 / 23,0$ & $20 / 24,7$ & $20 / 25,9$ & - & $20 / 5,3$ \\
\hline
\end{tabular}

Вихідні суміші готували змішуванням компонентів в барабанному змішувачі або розмелюванням в планетарному млині при співвідношенні маси шихти до маси розмельних тіл 1:10. Швидкість обертання барабанів млина становила близько 800 об./хв., тривалість розмелювання - 60 хв. 3 метою недопущення окислення і сегрегації частинок порошків цей процес проводили в середовищі етилового спирту.

3 отриманої суміші пресували циліндричні заготовки під тиском 700 МПа. Спікання отриманих пресовок здійснювали в контейнері 3 плавким затвором при температурі $1200{ }^{0} \mathrm{C}$ в печі Termolab CHOЛ 15/1300 або у вакуумній індукційній печі при $1250-1300{ }^{\circ} \mathrm{C}$. Тривалість ізотермічної витримки при спіканні становило 1 годину.

Гаряче штампування пресовок проводили в напівзакритому штампі (рис. 1) на дугостаторному пресі ФБ1732 з нагріванням вихідних заготовок в шахтній печі при $1100{ }^{0} \mathrm{C}$ в середовищі аргону. Щільність і пористість отриманих сплавів визначали методом гідростатичного зважування. Твердість вимірювали на твердомірі ТК-14-250 по ГОСТ 9013-75, а основні характеристики міцності (межу пропорційності $\sigma_{0,01}$, межу плинності $\sigma_{0,2}$, межу міцності $\sigma_{p}$ ) отриманих матеріалів визначали шляхом випробування зразків на стиск на універсальній випробувальній машині “CERAMTEST” згідно ГОСТ 25.503-97.

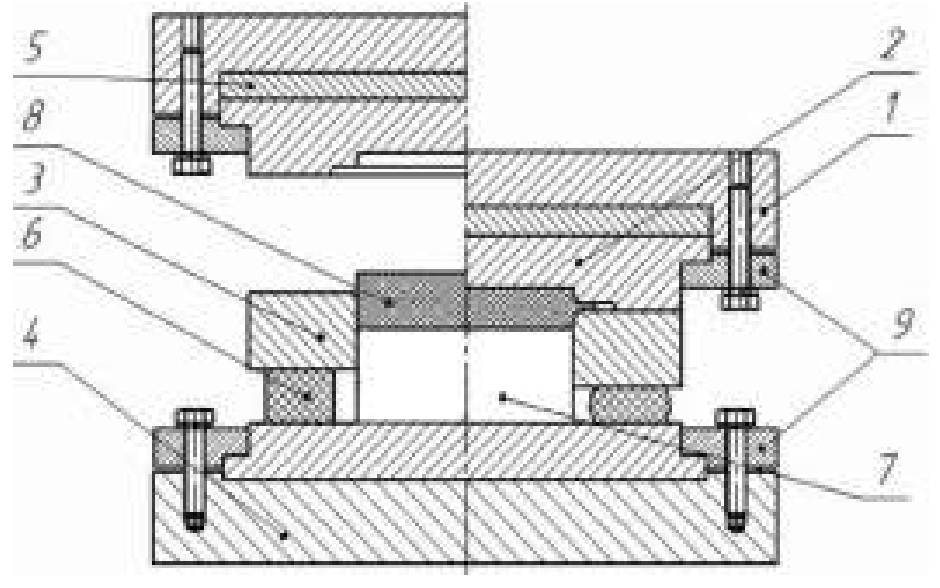

Рис. 1. Експериментальний штамп для гарячого штампування:

1 - верхня плита; 2 - верхня напівматриця; 3 - нижня напівматриця; 4 - нижня опорна плита; 5 - опорна пластина; 6 - пружний елемент; 7 - нижній пуансон; 8 - заготовка, що штампується; 9 - верхній і нижній кріпильні фланці 
Мікроструктуру сплавів вивчали на оптичному мікроскопі XJL-17 i на скануючому електронному мікроскопі JEOL Superprobe 733. Рентгенофазовий аналіз зразків здійснювали на приладі ДРОН-3 в відфільтрованому Со-К ${ }_{\alpha}$ випромінюванні методом покрокового сканування в діапазоні кутів 20-130. Зразок під час дифрагування обертався навколо своєї осі.

Результати дослідження морфології та гранулометричного складу вихідних порошкових сумішей і шихт після розмелювання в планетарному млині показали (рис. 2), що складові вихідної суміші являють собою частинки близькою до сферичної, рівновісної або осколкової форми (рис. 2, а, б); в результаті інтенсивної пластичної деформації в процесі механічної обробки даних сумішей в планетарному млині вони набувають пластинчату і лускату форму (рис. 2, в, г).

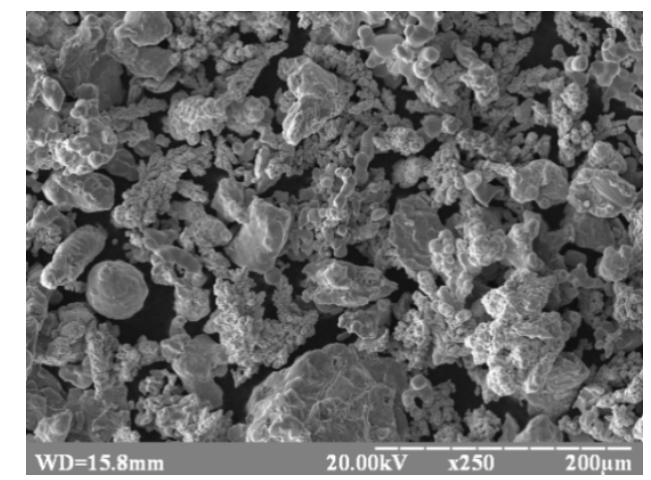

a

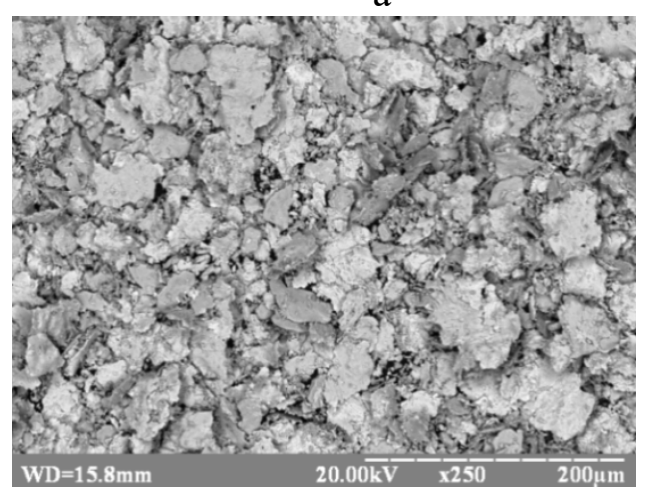

B

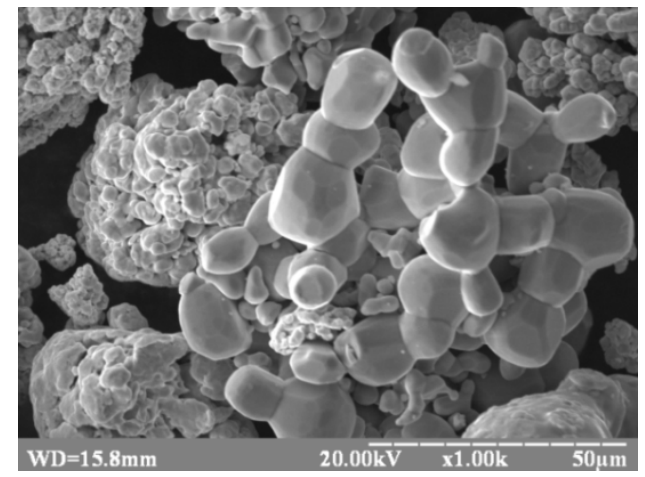

б

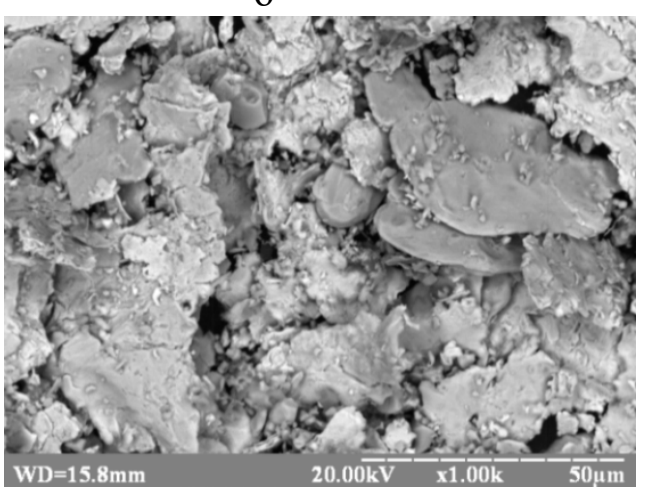

$\Gamma$

Рис. 2. Морфологія вихідної порошкової суміші складу $\mathrm{TiCrFeNiCu}(\mathrm{a}$, б) і після iï розмелювання протягом 60 хв. (в, г)

У процесі розмелювання дисперсність суміші значно зростає, а фракційний склад зміщується в бік ультрадисперсних фракцій (рис. 3).

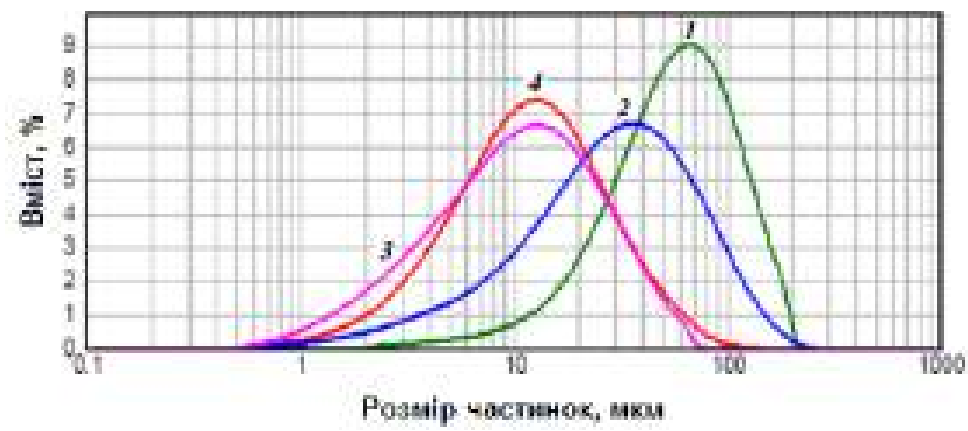

Рис. 3. Фракційний склад шихти $\mathrm{TiCrFeNiCu:} \mathrm{вихідна} \mathrm{суміш} \mathrm{(1)} \mathrm{i} \mathrm{шихта} \mathrm{після}$ розмелювання протягом 30 хв. (2), 60 хв. (3) та 120 хв. (4) 
Найбільш інтенсивне подрібнення суміші відбувається протягом перших 60 хв., тоді як збільшення тривалості розмелювання до 120 хв. не тільки не призводить до помітного збільшення дисперсності в порівнянні з порошком, размеленим протягом 60 хв., але і навіть і дещо знижує вміст ультрадисперсних фракцій (1-5 мкм) внаслідок агломерації дисперсних частинок при тривалому механічному впливі.

Такого роду зміна дисперсності і морфології частинок суміші викликає помітне зниження насипної густини для всіх досліджуваних сумішей (рис. 4).

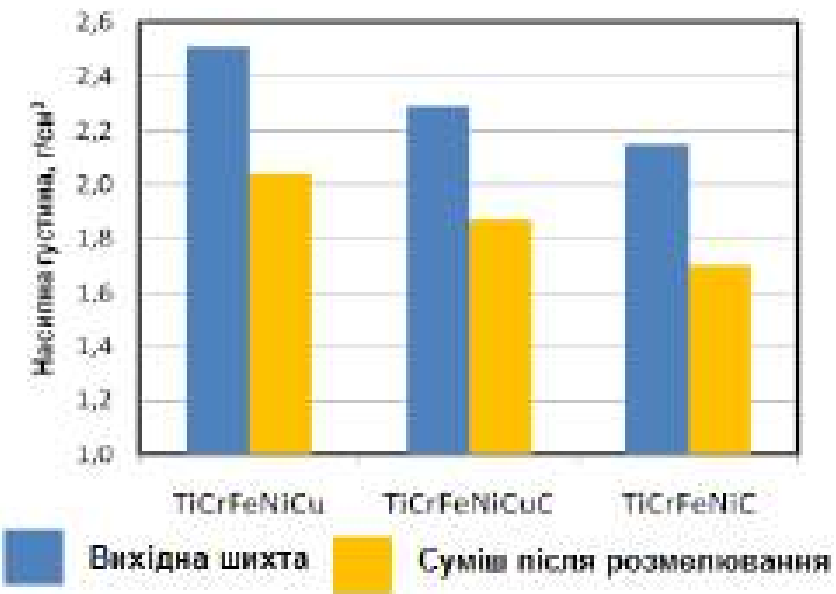

Рис. 4. Насипна густина вихідних порошкових сумішей і сумішей після розмелювання протягом 60 хв.

Оцінка ущільнюваності сумішей при їх пресуванні показала (рис. 5), що розмелювання шихти призводить до істотного зниження щільності пресовок при однакових тисках пресування. Так, якщо щільність зразків, спресованих при тиску 700 МПа з вихідних порошко-

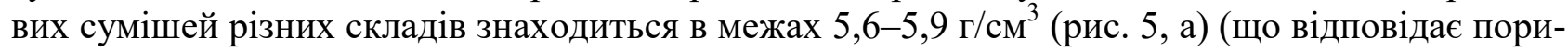
стості $\Theta=10-14 \%$ (рис. 5, в)), то після розмелювання їх щільність не перевищує

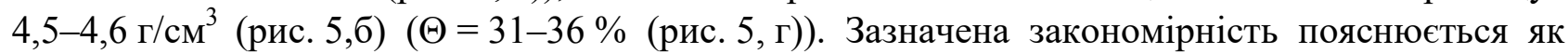
специфічною морфологією розмелених порошків, так і значним деформаційним зміцненням їх металевої складової в процесі розмелювання.

Аналіз результатів вивчення рентгенівських спектрів вихідних сумішей складу $\mathrm{TiCrFeNiCu}$ i після їх розуміли в планетарної млині протягом 30-120 хвилин показав, що незалежно від тривалості розмелювання в досліджуваному часовому інтервалі рентгенівський спектр зразків складається з рефлексів окремих компонентів, що входять до складу отриманого сплаву. 3 цього випливає висновок про відсутність будь-якого помітного хімічного взаємодії між компонентами в процесі розмелювання.

У той же час, зі збільшенням тривалості розмелювання інтенсивність дифракційних ліній решітки ОЦК, ГЦК і ГПУ знижується одночасно з їх розширенням. Так, після розмелювання протягом 60 і 120 хв. розширення ліній настільки велике, а інтенсивність настільки знижена, що рефлекси $\mathrm{Cu} 311, \mathrm{Ni311,} \mathrm{i} \mathrm{Cu222} \mathrm{ГЦК} \mathrm{решітки} \mathrm{практично} \mathrm{знаходяться} \mathrm{на} \mathrm{рівні}$ фону. Це свідчить про накопичення дефектів кристалічної будови і істотному спотворенні кристалічної решітки всіх компонентів, що проявляється в ефекті розширення ліній зі збільшенням тривалості розмелювання.

Після спікання при $1200{ }^{\circ} \mathrm{C}$ прессовок, отриманих з шихти, що не піддавалася попередньому розмелюванню, пористість зразків знижалася до 5,1-6,3\%. Попередня механоактивація суміші сприяла помітній інтенсифікації усадки при спіканні, проте внаслідок високої пористості вихідних пресовок, отриманих з розмелених сумішей (31-37\%) (рис. 5), пористість спечених із них зразків залишалася досить високою (в межах 10-14 \%) (рис. 6). 

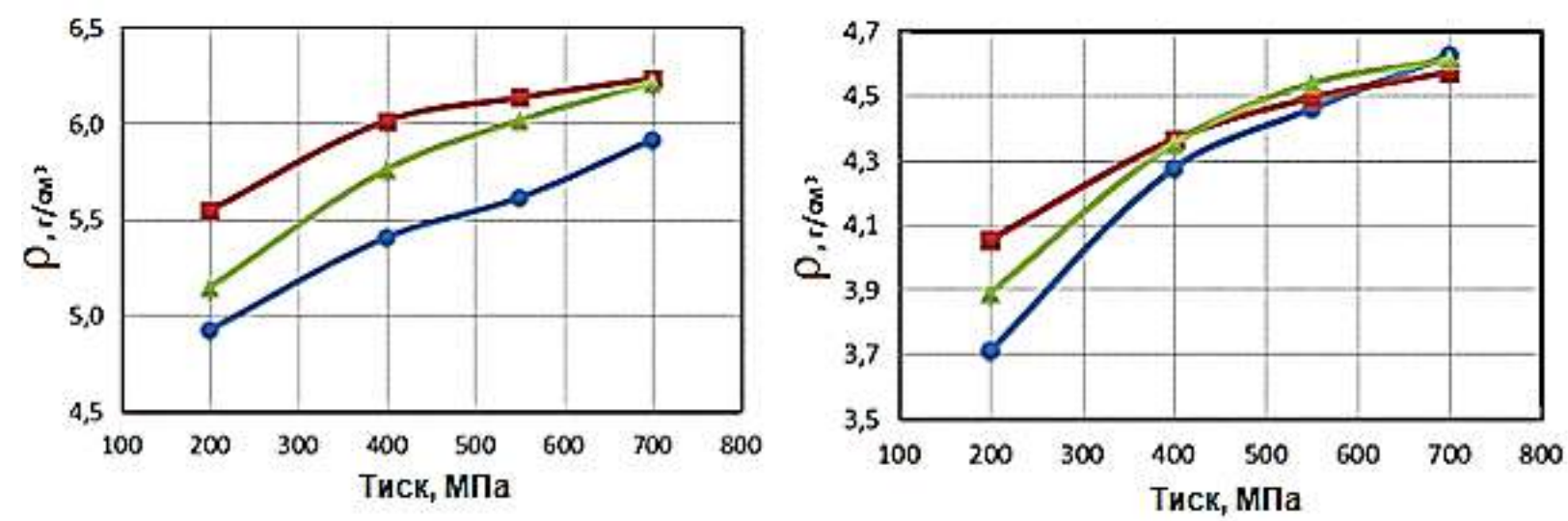

a.

TiCrFeNiCu $₫$ TiCrFeNiCuC 6

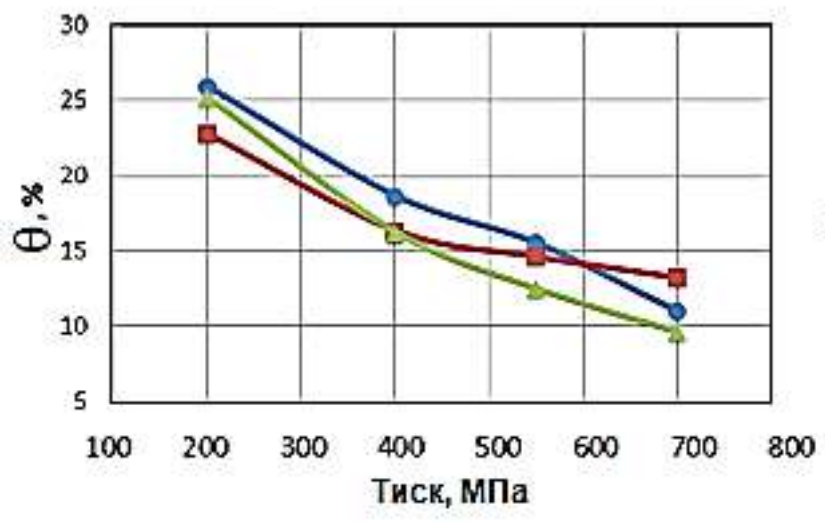

B

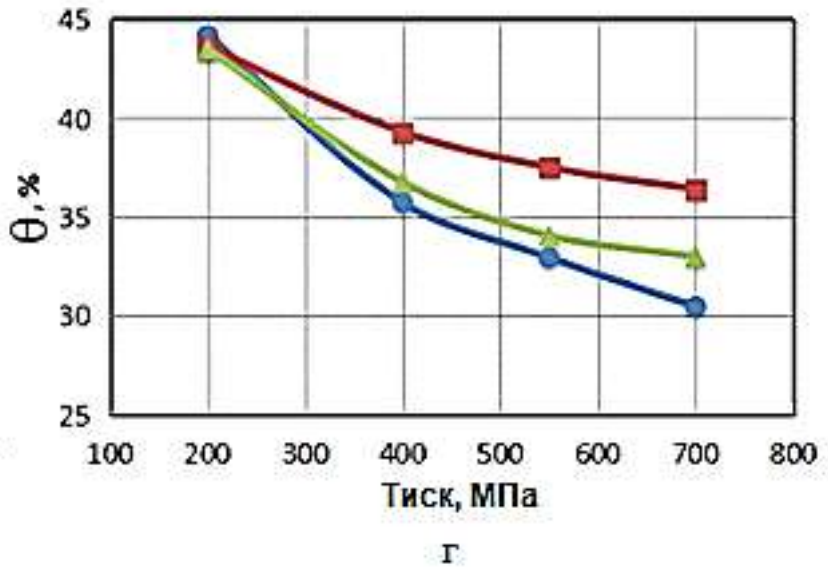

Рис. 5. Залежність густини $\rho(\mathrm{a}, 6)$ і пористості $\theta(\mathrm{B}$, г) прессовок від тиску пресування для вихідних порошкових сумішей (a, в) і сумішей після розмелювання протягом 60 хв. (б, г)

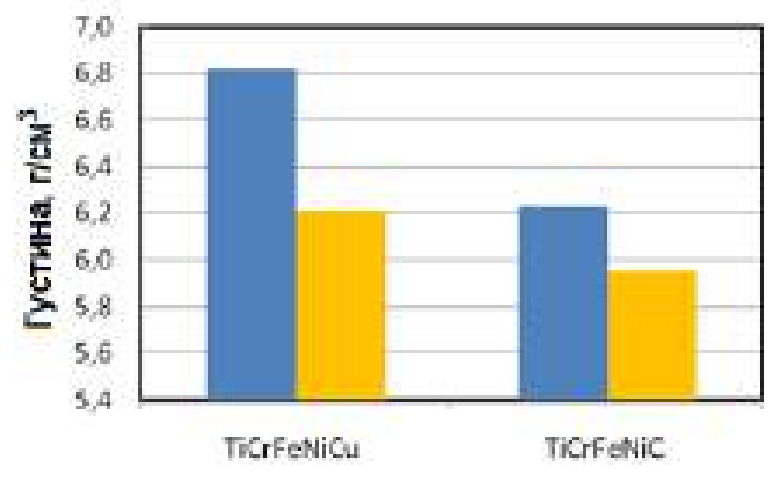

Вихідна суміш

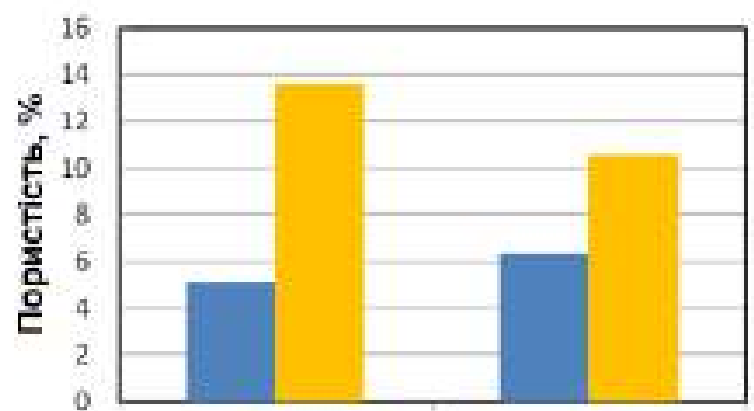

TiCrFeNiCu

TiCrFeNic

Шихта після розмелювання

б

Рис. 6. Густина (а) і пористість (б) пресовок, отриманих з вихідної суміші і суміші, що зазнала механоактивації, після спікання при $1200{ }^{\circ} \mathrm{C}$

Мінімізація пористості зразків (до 1-1,5 \%) була досягнута тільки при використанні гарячого штампування пористих заготовок із сумішей всіх досліджених складів. При цьому, попередня механоактивація порошкової суміші практично не чинила впливу на пористість матеріалів після штампування. У той же час, після відпалу гарячештампованих поковок при $1000-1250{ }^{\circ} \mathrm{C}$ спостерігається деяке зростання пористості (до 2-2,5\%), обумовлене впливом ефекту Френкеля II-го роду, що проявляється у формуванні в процесі спікання вторинної пористості внаслідок відмінності коефіцієнтів взаємної гетеродифузіі складових сплаву. 
Порівняльний аналіз мікроструктур спечених і гарячештампованих сплавів однакових складів показали їх істотну відмінність. Так, в процесі спікання безвуглецевого сплаву системи $\mathrm{TiCrFeNiCu}$ утворюються дві фази твердого розчину: зі структурою матричної ГЦК і відносно великих включень (з розміром зерен до 20 мкм) ОЦК фази (сіра і світла фази відповідно, рис. 7, а), ідентифіковані за результатами рентгенофазового аналізу.

На відміну від спечених сплавів, структура гарячештампованих зразків суттєво більш дисперсна і відрізняється наявністю істотної анізотропії з формуванням своєрідних квазіволокон, орієнтованих в напрямку, перпендикулярному напрямку прикладання деформуючого зусилля при гарячому штампуванні (рис. 7, б).

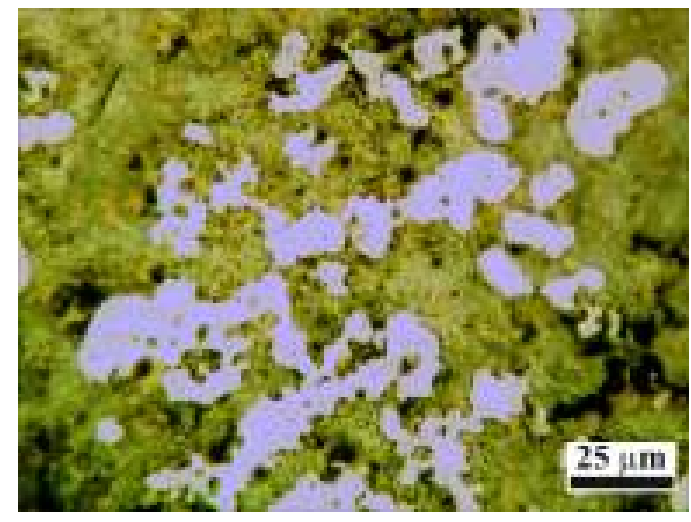

a

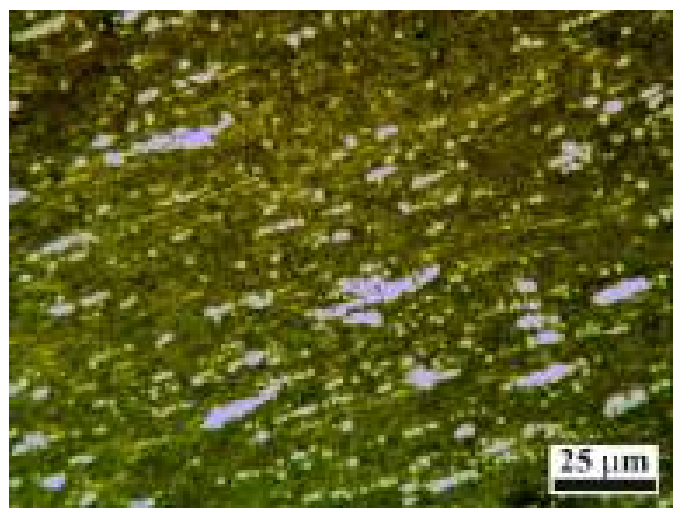

6

Рис. 7. Мікроструктури спеченого при $1200{ }^{\circ} \mathrm{C}$ (а) та гарячештампованого (б) сплаву $\mathrm{TiCrFeNiCu}$

Введення до складу вихідної суміші вуглецю (склад № 3, табл. 1) призвело до істотних змін структури та фазового складу спеченого сплаву. Рентгенівський спектр сплаву представлений нарівні із переважаючими лініями ГЦК структурної складової включає інтенсивні лінії карбіду титану $\mathrm{TiC}$ з ГЦК гратами та лінії карбіду хрому $\mathrm{Cr}_{3} \mathrm{C}_{2}$. Мікроструктура спеченого при $1300{ }^{\circ} \mathrm{C}$ сплаву системи $\mathrm{TiCrFeNiC}$ являє собою матричну високоентропійну ГЦК фазу 3 рівномірно розподіленими дисперсними включеннями карбідів $\mathrm{TiC}$ i $\mathrm{Cr}_{3} \mathrm{C}_{2}$ (рис. 8).

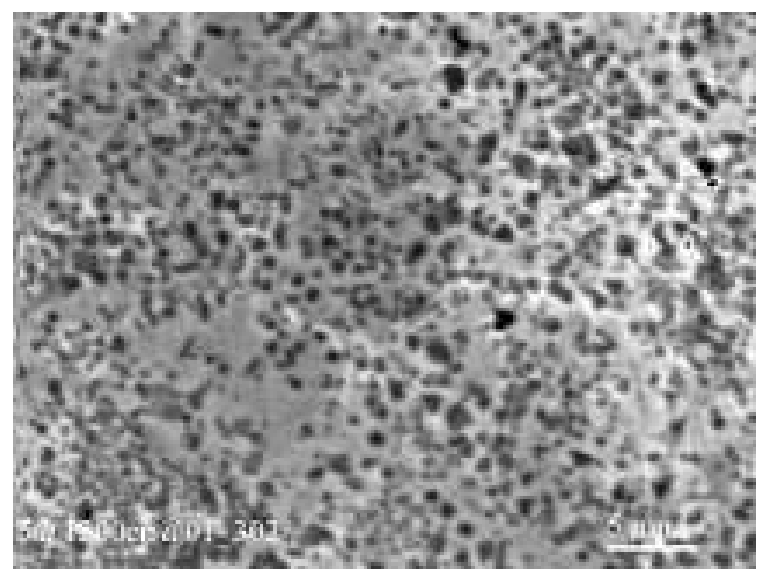

Рис. 8. Мікроструктура спеченого при $1300{ }^{\circ} \mathrm{C}$ сплаву TiCrFeNiC

Мікроструктура гарячештампованого сплаву системи $\mathrm{TiCrFeNiC}$ також включає матричну фазу на основі ГЦК решітки, і двох карбідних фаз. Сплави безпосередньо після гарячого штампування, а також подальшого відпалу при 1200 та $1250{ }^{\circ} \mathrm{C}$ характеризуються наяв- 
ністю специфічної шаруватої структури, характерної для гарячештампованих порошкових матеріалів [17] з шарами товщиною до 10 мкм, орієнтованими в напрямку, перпендикулярному напрямку прикладання деформуючого зусилля при штампуванні (рис . 9, а-в).

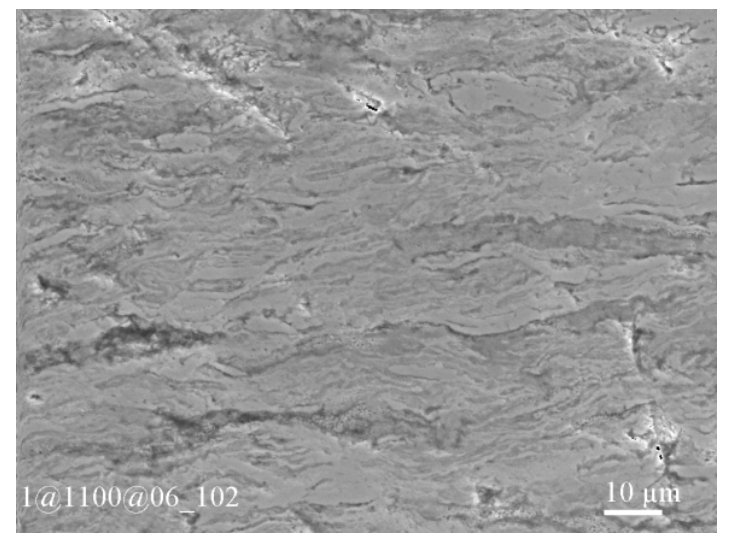

$\mathrm{a}$

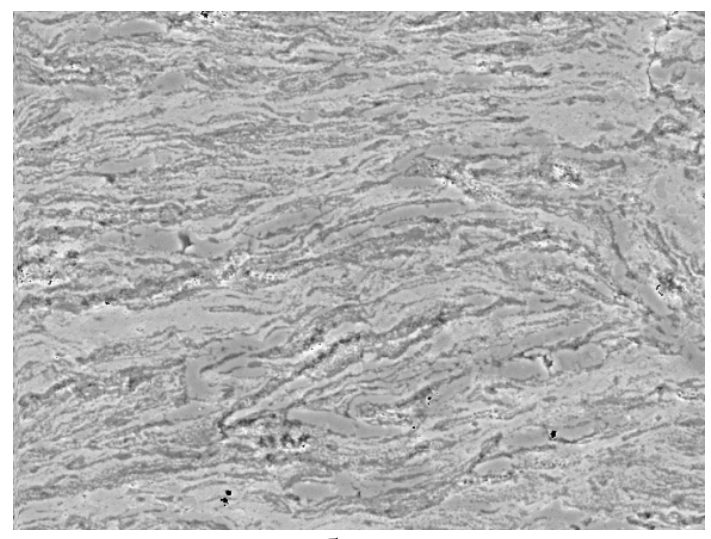

6

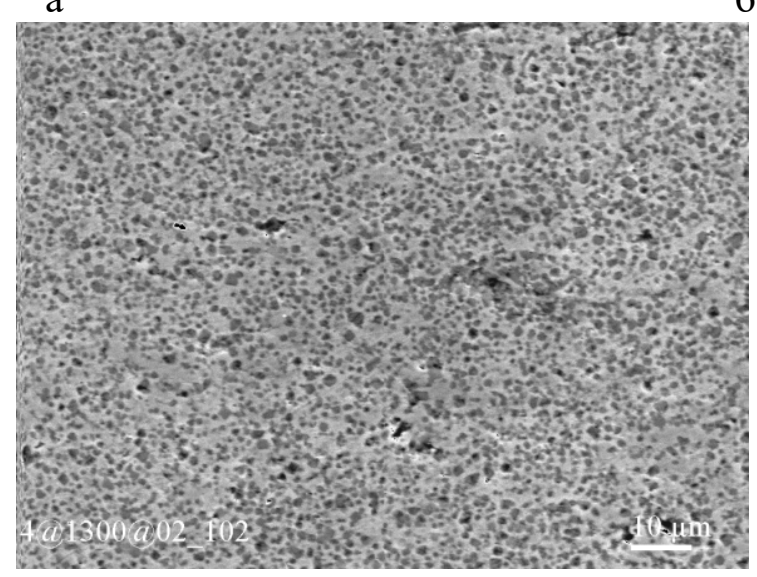

B

Рис. 9. Мікроструктури гарячештампованого сплаву $\mathrm{TiCrFeNiC} \mathrm{після} \mathrm{гарячого} \mathrm{штам-}$ пування (а) і відпалу при 1200 (б) і 1300 C (в)

У той же час, характер мікроструктури сплаву після відпалу при $1300{ }^{\circ} \mathrm{C}$ істотно відрізняється від попередніх. Відбувається сфероідізація матричної фази, яка тепер представлена округлими (еліпсоїдними) зернами діаметром 10-30 мкм (рис. 9, г). Очевидно, цей ефект може бути обумовлений початком плавлення при $1290{ }^{\circ} \mathrm{C}$, що супроводжується появою помітної кількості рідкої фази при підвищенні температури відпалу з подальшою перекристалізацією, що підтверджено даними диференціального термічного аналізу (рис. 10).

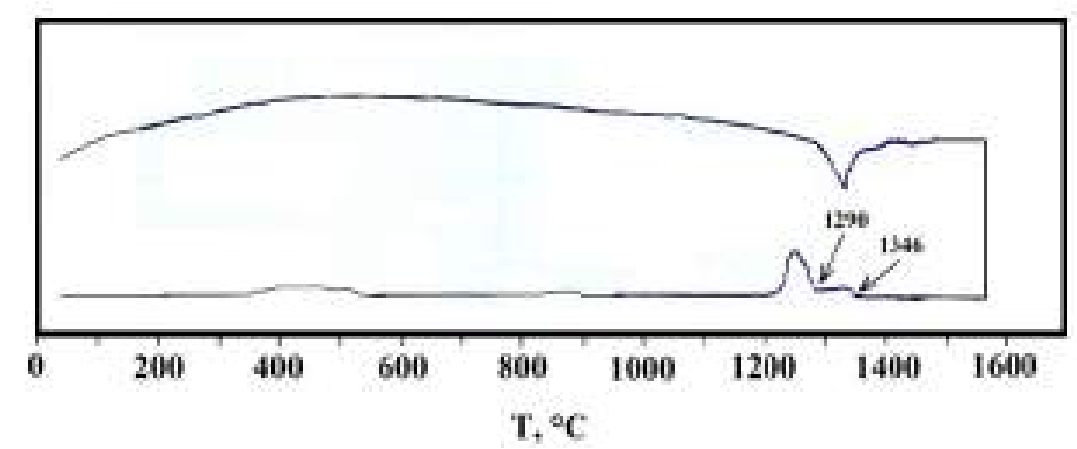

Рис. 10. ДТА термограма еквіатомного сплаву TiCrFeNiC 
Оцінка основних механічних характеристик досліджених сплавів показала, що найбільшими значеннями твердості (рис. 11) відрізняється сплав $\mathrm{TiCrFeNiC,} \mathrm{отриманий} \mathrm{гарячим}$ штампуванням. При цьому, твердість гарячештампованих сплавів закономірно помітно вища, ніж спечених, що обумовлено істотно більш високими значеннями пористості спечених матеріалів у порівнянні з практично безпористими гарячештампованими сплавами.

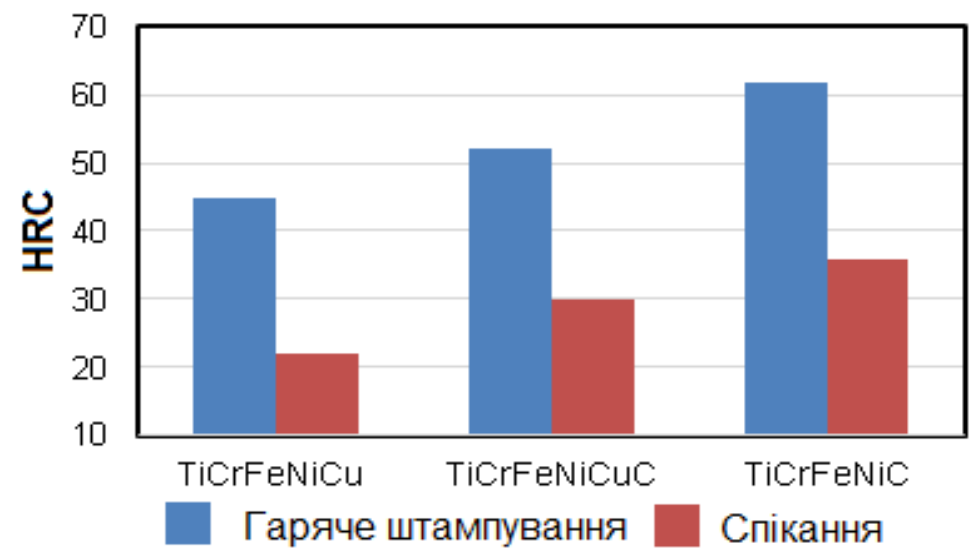

Рис. 11. Твердість спечених і гарячештампованих еквіатомніх сплавів різних компонентних складів

Враховуючи отримані результати щодо твердості та пористості спечених і гарячештампованих висоентропійних сплавів що вказують на значні переваги властивостей гарячештампованих матеріалів у порівнянні зі спеченими, подальші дослідження базувалися на оцінці властивостей саме гарячештампованих зразків.

Як показали результати дослідження, аналогічно з твердістю найвищими значеннями характеристик міцності відзначається вуглецьвміщюючий гарячештампований сплав $\mathrm{TiCrFeNiC:} \mathrm{межа} \mathrm{плинності} \sigma_{0,2}$ вказаного сплаву після штампування та відпалу при $1200{ }^{0} \mathrm{C}$ перевищує значення 1560 МПа, а межа міцності $\sigma_{\mathrm{p}}$ досягає 1970 МПа (рис. 12,a).

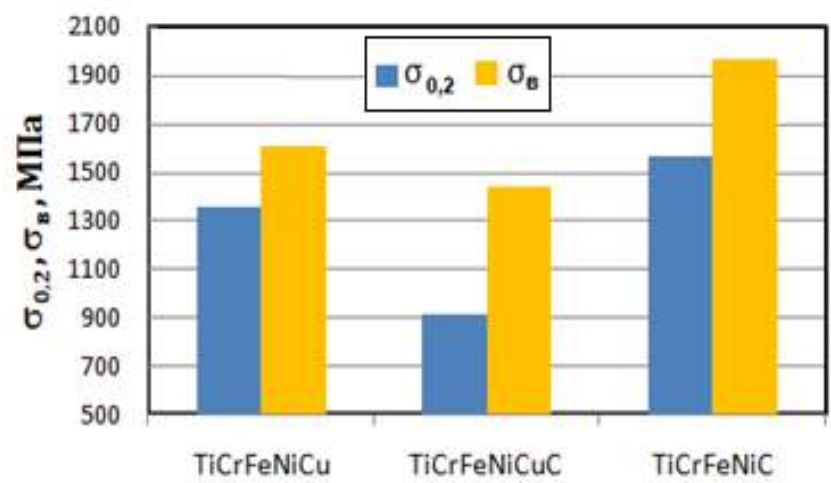

a

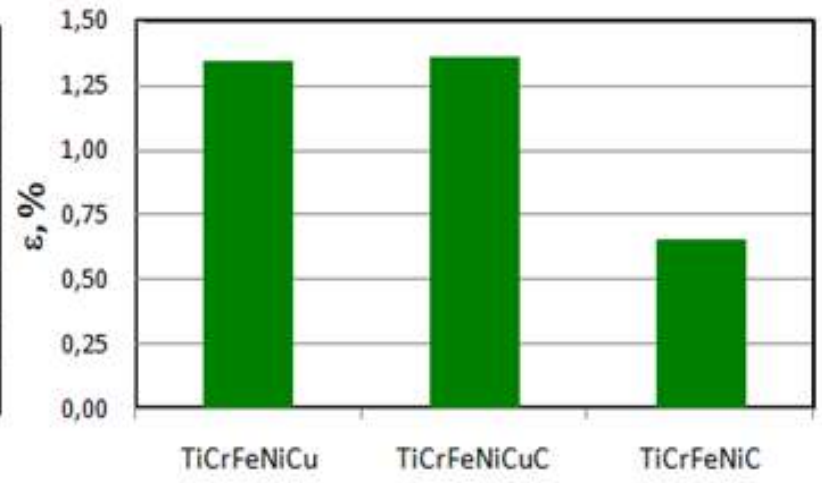

6

Рис. 12. Характеристики параметрів міцності (а) і пластичності (б) гарячештампованих сплавів після відпалу при $1200{ }^{\circ} \mathrm{C}$

Очевидно, достатньо високі значення твердості і особливо міцності еквіатомного сплаву $\mathrm{TiCrFeNiC} \mathrm{у} \mathrm{порівнянні} \mathrm{з} \mathrm{іншими} \mathrm{досліджуваними} \mathrm{сплавами} \mathrm{пов'язані} \mathrm{перш} \mathrm{за} \mathrm{все}$ 
3 двома факторами - проявом ефекту значного спотворення кристалічної решітки та in situ формуванням у складі сплаву карбідних фаз титану і хрому.

Поряд 3 досить високими характеристиками міцності досліджених сплавів, звертає на себе увагу вкрай низька пластичність (рис. 12, б), обумовлена переважним вмістом в структурі сплаву твердорозчинної ГЦК фази з високою дефектністю кристалічної структури.

Оцінка впливу температури відпалу на характеристики міцності і пластичності для еквіатомного сплаву $\mathrm{TiCrFeNiC}$ показала (рис. 13), що застосування відпалу гарячештампованих зразків та збільшення температури останнього з 1200 до $1300{ }^{\circ} \mathrm{C}$ сприяє підвищенню пластичності (рис. 13, б) і тріщиностійкості (рис. 13, в) при деякому зниженні його міцності (рис. 13, а) у порівнянні з вихідним гарячештампованим сплавом.

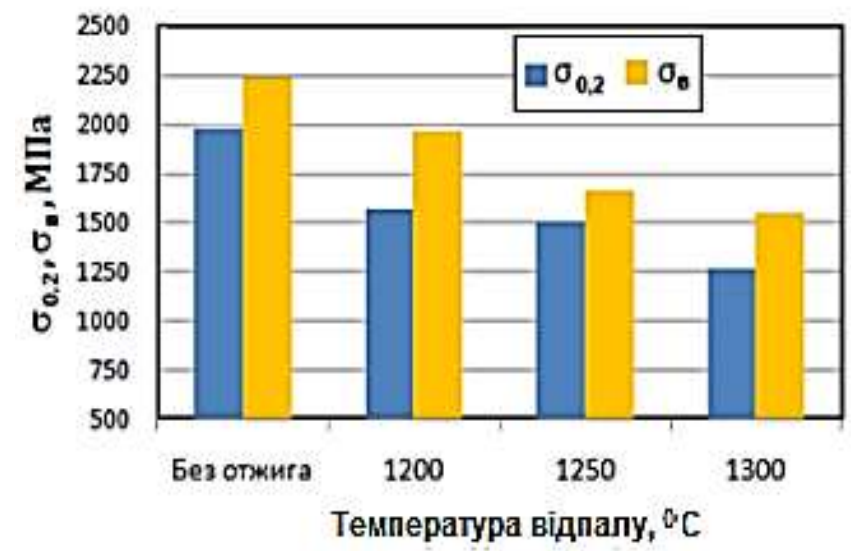

a

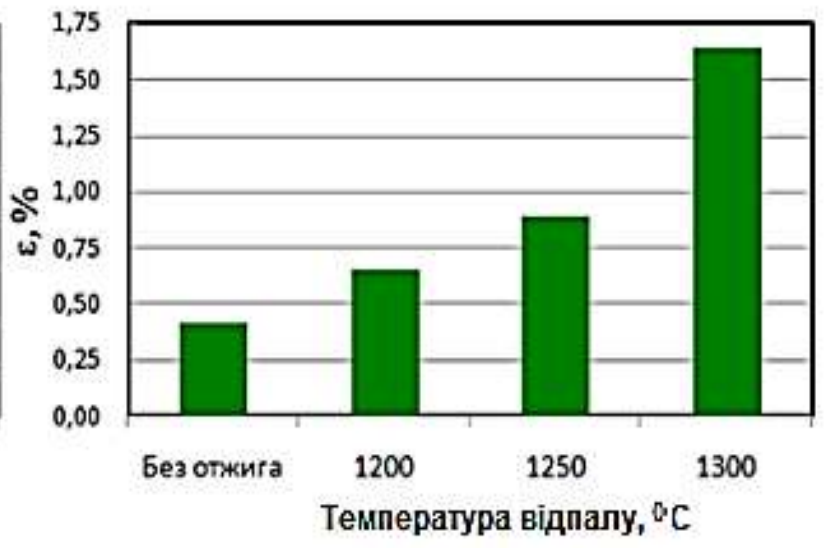

6

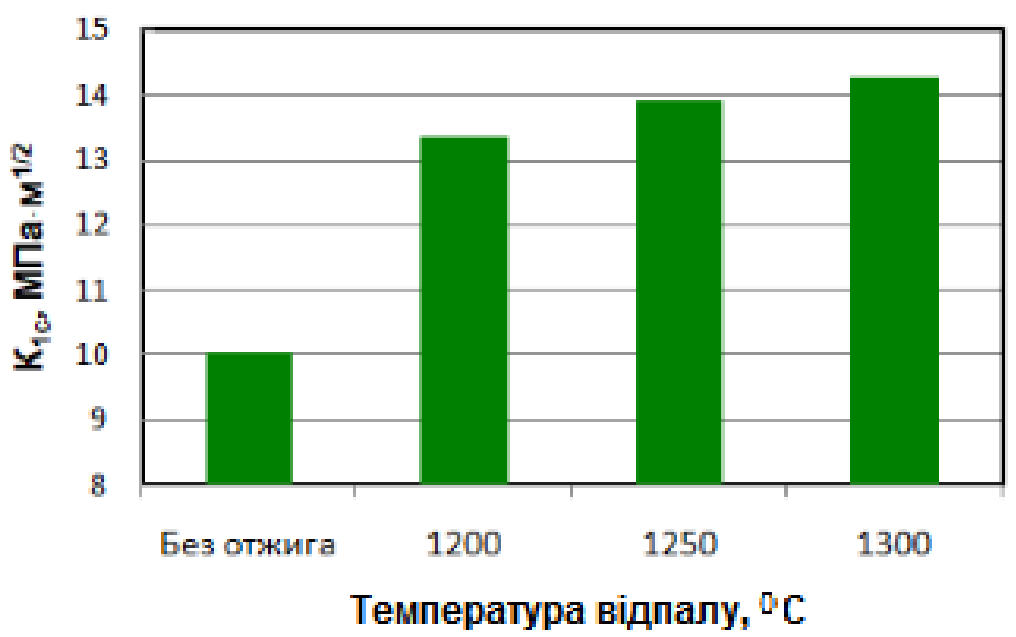

B

Рис. 13. Залежність міцності (а), пластичності (б) і тріщиностійкості (в) гарячештампованого еквіатомного сплаву $\mathrm{TiCrFeNiC} \mathrm{від} \mathrm{температури} \mathrm{відпалу}$

Відмічена закономірність обумовлена особливостями еволюції структури гарячештампованих матеріалів, що відбуваються при їх відпалі та проявляється, зокрема, при аналізі результатів фрактографічних досліджень поверхонь зламів досліджуваного сплаву (рис. 14). Як можна бачити 3 рис. 14, а, руйнування гарячештампованих зразків, що не піддавалися відпалу, носить головним чином транскристалітний характер, тоді як після відпалу при $1300{ }^{\circ} \mathrm{C}$ на зламі спостерігається помітне кількість осередків інтеркрісталітного зламу (рис. 14, б), що сприяє підвищенню характеристик пластичності і тріщиностійкості сплаву. 


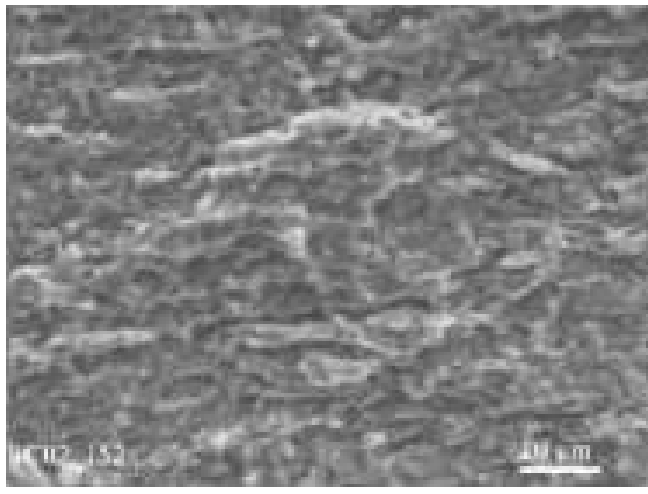

$\mathrm{a}$

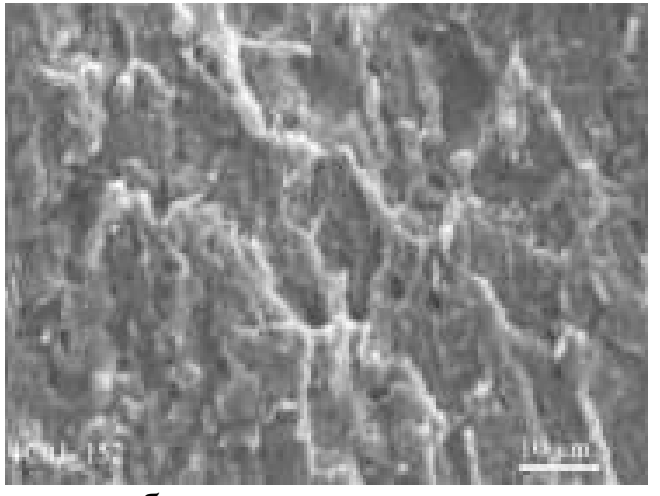

6

Рис. 14. Структура поверхонь зламу еквіатомного сплаву $\mathrm{TiCrFeNiC} \mathrm{після} \mathrm{гарячого}$ штампування (а) і подальшого відпалу при 1300 $\mathrm{C}$ (б)

\section{ВИСНОВКИ}

Показана ефективність застосування гарячого штампування для отримання полікомпонентних високоентропійних сплавів на основі системи $\mathrm{TiCrFeNi}$, що забезпечує високу щільність, близьку до теоретичної, і істотне диспергування структурних елементів сплавів у порівнянні зі спеченими сплавами аналогічних компонентних складів.

Гаряче штампування призводить до формування специфічної шаруватої структури 3 шарами товщиною до 10 мкм, орієнтованими в напрямку, перпендикулярному напрямку прикладання деформуючого зусилля при штампуванні, які зберігаються і після відпалу при 1200 та $1250{ }^{\circ} \mathrm{C} .3$ підвищенням температури відпалу до $1300^{\circ} \mathrm{C}$ відбувається сфероідізація матричної фази, яка представлена округлими (еліпсоїдними) зернами розміром 10-30 мкм.

Серед досліджених сплавів найбільшими значеннями твердості (HRC 62) і міцності на стиск (2243 MПа) відзначається сплав $\mathrm{TiCrFeNiC}$, отриманий гарячим штампуванням. Такі характеристики твердості і особливо міцності еквіатомного сплаву обумовлені проявом ефекту спотворення кристалічної решітки та in situ формуванням у складі сплаву карбідних фаз титану і хрому.

\section{СПИСОК ВИКОРИСТАНОЇ ЛІТЕРАТУРИ}

1. Ranganathan S. Alloyed pleasures: Multimetallic coctails. Current Science. 2003. 85. 10, pp. 1404-1406.

2. Yeh J.W. High-Entropy Alloys - A New Era of Exploitation. Materials Science Forum. 2007. 560, pp. 1-9.

3. Yeh J.W. Recent progress in high-entropy alloys. Ann. Chim. Sci. Mat. 2006. 31, pp. 633-648.

4. Фирстов С.А. Горбань В.Ф., Крапивка Н.А., Печковский Э.П. Новый класс материалов. высокоэнтропийные сплавы и покрытия. Вестник ТГУ. 2013. 18. 4. С. 1938-1940.

5. Древаль Л. А., Агравал П. Г., Турчанин М. А. Высокоэнтропийные сплавы как материалы, имеющие в основе множество базовых элементов. Вісник Донбаської державної машинобудівної академії. 2014.1 (32). C. 58-64.

6. Фирстов С.А., Горбань В.Ф., Крапивка Н.А. и др. Механические свойства многокомпонентного титанового сплава. Проблемы прочности. 2010. 5. С. 178-189.

7. Фирстов С.А., Горбань В.Ф., Крапивка Н.А. и др. Механические свойства литых многокомпонентных сплавов при высоких температурах. Сов. пробл. физич. Материаловедедения. 2008. 17. С. 126-139.

8. Chuang M. H. Tsai M. H., Wang W. R., Lin S. J., Yeh J. W. Microstructure and wear behavior of $\mathrm{Al}_{\mathrm{x}} \mathrm{Co} 1.5 \mathrm{CrFeNi1.5Ti}$ high-entropy alloys. Acta Mater. 2011. 59, pp. 6308-6317.

9. Liu Z., Guo S., Liu X., et al. Micromechanical characterization of casting-induced inhomogeneity in an Al0.8CoCrCuFeNi high-entropy alloy. Scripta Materialia. 2011. 64, pp. 868-871.

10. Fan Y.H., Zhang Y.P., Guan H.G., Suo H.M., He L. AlNiCrFexMo0.2CoCu High Entropy Alloys Prepared by Powder Metallurgy. Rare Metal Materials and Engineering. 2013. 42, 6, pp. 1127-1129.

11. Qiu X.W. Microstructure and properties of $\mathrm{AlCrFeNiCoCu}$ high entropy alloy prepared by powder metallurgy. Journal of Alloys and Compounds. 2013. 555, pp. 246-249.

12. Дорофеев Ю.Г., Гасанов Б.Г., Дорофеев В.Ю. и др. Промышленная технология горячего прессования порошковых изделий. М.: Металлургия. 1990. 206 с.

13. Hendrickson A.A., Machmeier P.M., Smith D.W. Impact forging of sintered steel preforms. Powder Metallurgy. 2000. 43, 4, pp. 327-344. 
14. Баглюк Г.А. Влияние деформационных параметров на структуру и свойства горячештампованных порошковых материалов. Обработка материалов давлением. Краматорск: ДГМА. 2011.1 (26). С. 139-145.

15. Дорофеев В.Ю., Егоров С.Н. Межчастичное сращивание при формировании порошковых горячедеформированных материалов. Москва: ЗАО Металлургиздат, 2003. 152 с.

16. Павлов В.А., Носенко М.И. Влияние горячей деформации на формирование структуры и свойств порошковых металлов. Порошковая металлургия. 1988. 2. С. 16-20.

17. Баглюк Г.А., Безымянный Ю.Г., Стасюк А.А. и др. Влияние горячей штамповки на упругие свойства и характер анизотропии порошковых металломатричных композитов. Порошковая металлургия: Инженерия поверхности. Новые порошковые композиционные материалы. Сварка: Сб. докл. 11-го международн. симпозиума. Минск. 10-12 апреля 2019 г. С. 409-424.

\section{REFERENCES}

1. Ranganathan S. Alloyed pleasures: Multimetallic coctails. Current Science. 2003. 85. 10, pp. 1404-1406.

2. Yeh J.W. High-Entropy Alloys - A New Era of Exploitation. Materials Science Forum. 2007. 560, pp. 1-9.

3. Yeh J.W. Recent progress in high-entropy alloys. Ann. Chim. Sci. Mat. 2006. 31, pp. 633-648.

5. Dreval L.A., Agraval P.G., Turchanin M.A. High-entropy alloys as materials having a set of basic elements in the base. Herald of the DSEA. Kramatorsk: DSEA. 2014. 1 (32), pp. 58-64. (in Russian).

6. Firstov S.A., Gorban V.F., Krapivka N.A. and other Mechanical properties of multicomponent titanium alloy. Strength problems. 2010. 5, pp. 178-189. (in Russian).

7. Firstov S.A., Gorban V.F., Krapivka N.A. and other Mechanical properties of cast multicomponent alloys at high temperatures. Modern problems of physical materials science. 2008. 17, pp. 126-139. (in Russian).

8. Chuang M.H. Tsai M.H., Wang W.R., Lin S.J., Yeh J.W. Microstructure and wear behavior of $\mathrm{Al}_{\mathrm{x}-}$

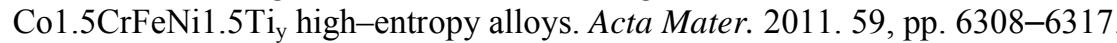

9. Liu Z., Guo S., Liu X., et al. Micromechanical characterization of casting-induced inhomogeneity in an Al0.8CoCrCuFeNi high-entropy alloy. Scripta Materialia. 2011. 64, pp. 868-871.

10. Fan Y.H., Zhang Y.P., Guan H.G., Suo H.M., He L. AlNiCrFexMo0.2CoCu High Entropy Alloys Prepared by Powder Metallurgy. Rare Metal Materials and Engineering. 2013. 42, 6, pp. 1127-1129.

11. Qiu X.W. Microstructure and properties of $\mathrm{AlCrFeNiCoCu}$ high entropy alloy prepared by powder metallurgy. Journal of Alloys and Compounds. 2013. 555, pp. 246-249.

12. Dorofeev Yu.G., Gasanov B.G., Dorofeev V.Yu., et al. Industrial technology of hot pressing of powder products. Moscow: Metallurgy. 1990. 206 p. (in Russian).

13. Hendrickson A. A., Machmeier P. M., Smith D. W. Impact forging of sintered steel preforms. Powder Metallurgy. 2000. 43. 4, pp. 327-344.

14. Bagliuk G.A. Influence of deformation parameters on the structure and properties of hot-stamped powder materials. Materials Working by Pressure. Kramatorsk: DSEA. 2011. 1 (26), pp. 139-145. (in Russian).

15. Dorofeev V. Yu., Egorov S.N. Interparticle splicing in the formation of powder hot-deformed materials. Moscow: Metallurgizdat, 2003. 152 p. (in Russian).

16. Pavlov VA, Nosenko MI Influence of hot deformation on the formation of structure and properties of powder metals. Powder metallurgy. 1988. 2, pp. 16-20. (in Russian).

17. Bagliuk G.A., Bezymyanny Yu.G., Stasyuk A.A., et. al. Influence of hot forging on elastic properties and the nature of anisotropy of powder metal-matrix composites. Powder Metallurgy: Surface Engineering. New powder composite materials. Welding: Sat. report 11th international symposium. Minsk. April 10-12 2019, pp. 409-424. (in Russian).

Баглюк Г. А. - д-р техн. наук, проф., заст. директора ІПМ НАН України; E-mail: gbag@ukr.net; https://orcid.org/0000-0003-4840-3346

Марич М. В. - мол. наук. співроб. ІПМ НАН України; E-mail: myroslavmv@ukr.net; https://orcid.org/0000-0003-3560-8238

Кирилюк С. Ф. - мол. наук. співр. ІПМ НАН України. E-mail: psihyha@gmail.com; https://orcid.org/0000-0002-3075-7720

IПМ - Інститут проблем матеріалознавства НАН України, м. Київ. 